\title{
Optimizing Stakeholder Role in Handling Conflict Between College of Pencak Silat Setia Hati Terate With Setia Hati Winongo
}

\author{
Rachman Fikri ${ }^{\text {a }}$, Irwan Noor ${ }^{\text {a }}$, Lely Indah Mindarti ${ }^{\text {a }}$ \\ ${ }^{a}$ Brawijaya Universitas, Malang, East Java, Indonesia
}

\section{INFORMASI ARTIKEL}

\section{Article history:}

Dikirim tanggal: December 05, 2019

Revisi pertama tanggal: March 03, 2020

Diterima tanggal: April 03, 2021

Tersedia online tanggal: May 31, 2021

Keywords: Stakeholder; synergy; social conflict policy.

\author{
ABSTRACT
}

The regency and City of Madiun became the cultural center of Pencak Silat school. There are 11 schools that are affiliated with IPSI. The eleventh of the school has its own Pencak Silat identity. Different identity of the schools raises conflicts, such as PPSHT with PPSHW. Conflicts often occur when doing the tradition of Suran Agung. The Regency and city Madiun government have made various efforts to implementation of Law No. 7 of 2012 about handling of social conflict but that has not been optimal. The research raised of the problem about how the optimisation pattern of stakeholder role in the handling of conflicts between PPSHT and PPSHW in the Regency and city of Madiun by conducting a perspective mapping of stakeholders involved. This research uses qualitative descriptive methods to focusing on 1) role policy Creator, 2) Coordinator, 3) facilitator, 4) Implementer and 5) accelerators in the handling of conflicts transformed into the development of Madiun tourism The Village of Indonesia Fighter. The results of this study revealed that not yet optimal role of each stakeholder in the handling of conflicts even less do a transformation of conflict into the development of Pencak Silat tourism destination. This is due to the absence of a policy derivative in the form in local regulations and has not yet synergitas the role of stakeholders between the regency government and the city of Madiun. So, there is interesting attraction to fight for the Icon of Pencak Silat and throwing responsibility for the conflicts that occur.

2021 FIA UB. All rights reserved.

\section{Introduction}

The public administration, according to Chandler and Plano (Keban, 2004) is a process of resource and public personnel organized and coordinated to formulate, implement, and manage decisions or public policies to Public affairs. Managing public affairs can be implied in the opening of the Constitution of the Republic of Indonesia in the 1945 year which provides the absolute will for the order of Indonesian law. The opening of the Constitution 1945 mentions 4 (four) national objectives of the Indonesian nation, which is to form a government of the Republic Indonesia that protects all of Indonesians and all the blood in Indonesia, advancing the general welfare, educate The life of the nation, as well as participating actively and participating in the order of the world based on independence, lasting peace and social justice.

In order to realize the four national objectives, Indonesian nation must have a healthy and strong psychic and physical. In addition to diplomacy, the physical struggle against and repel the invaders is the historical fact of the establishment of Indonesia (Kumaidah, 2012). The heroes use martial arts to repel the invaders and fight for independence.

One of the original martial arts of Indonesian ancestors is Pencak Silat. By Das Sollen Pencak Silat is

* Corresponding author. e-mail: rachmanfikri97@gmail.com 
expected to become the unifier and pride of the nation of Indonesia with a more sports performance at national and international levels. However, what should happen is not entirely in accordance with the fact that occurs (Das sein) (Kumaidah,2016). In fact, existence of Pencak Silat School precisely raises problems with the occurrence of the conflict between Silat colleges. regency and Madiun city is the center of Pencak Silat culture in Indonesia, but the advantage is not followed by a proud achievement, because of the lack of events as a medium of selection to capture athletes achievement.

Lack of events are caused by the fear of the fights between the masses involving two major colleges namely Pencak Silat Setia Hati Terate (PSHT) and Pencak Silat Setia Hati Winongo (PSHW) that took place since the 1990 year. According to Nurcahyo (2012) The difference of the teaching principle of the two Pencak Silat schools led by the two students of Ki Ngabehi Soerodiwirjo, as the time has changed into conflict accompanied by violence among followers and has caused many Casualties and community possessions.

The conflict between the fighters reaches its peak around the 1990-an and the intensity of the conflict occurs every year in the month of Suro when the fighters do a great Suran event (Temu Kadhang) by PSHW and pilgrimage to the tomb of the founding of Pencak Silat by PSHT. Based on the Madiun police data from March 1998 to February 2017 (as quoted in Maksum, 2017), there has been a 217 case of violence involving both Pencak Silat colleges, 180 cases occurred in Madiun District and 37 cases occurred in The Regional of Madiun. The intensity of the new conflict began to subside in 2015, which is 1 to 2 cases of fights. Decrease in conflict escalation because the government seeks to implement law number 7 year 2012 on social conflict handling article 8 that the resolution of disputes in the community is done peacefully by deliberation.

The government's effort is to improve the security pattern in reference to Law No. 7 of 2012 article 26 through The office of nation unity and politics of regency and Madiun City synergize with security personnel. The provisions of the legislation explaining the handling of conflicts should involve the synergity of the influential stakeholders and directly related to the handling of conflicts. So far, various has been done in particular by the security forces (district Police and Madiun City and Military District Command Office 0803/ Madiun) as well as local governments and cities (The office of nation unity and politics of regency and Madiun City) from forming the Paguyuban Madiun Kampung Pesilat as a means of communication inter-leadership of Pencak Silat College, coaching up to package security patterns persuasive, humanist and the Internal Safety Unit of Pencak Silat College, but overall have not received results As expected.

Prolonged conflict between PSHT and PSHW is not allowed to be protracted so that every year there is always a change in security patterns due to the absence of standard regulatory standards (Local Regulations or SOP) as implementation guidelines involving the role of stakeholder involved as stipulated in the Law Number 7 of year 2012 that the handling of conflicts is not only a business of the Indonesian Army and Indonesian Police but also the role of all device organizations Related Regionals.

From this description the optimization of stakeholder role is very important because it is based on government Regulation Number 2 of year 2015 on the implementation of social conflict handling chapters 2, 7, 20, 40 and 41 that the entire operational procedures of handling A conflict takes synergity between stakeholders in order to optimally conduct ongoing prevention. Without clear rules and involve all stakeholders, then year after year will continue to occur attracting interest between the followers of Pencak Silat and security personnel. For sure, the achievement of Pencak Silat and efforts to realize Madiun as the village of Pesilat will be further away from the expectations of all parties. And like what has been said by Minister of Youth and Sports Madiun Imam Nahrowi on his visit 18 March 2017 that Madiun deserves to be a world Silat village.

Transformation of conflict into this tourist destination also delivered by the Regent of Madiun period 2018 2023, H. Ahmad Dawami Ragil Saputro, S. Sos which has a vision of mission, safe, independent, prosperous and moral. A preliminary program that has been implemented to realize its mission and vision are to create a safe and conducive condition of Madiun regency, so as to realize the Madiun Regent embraced all Pencak Silat schools in Madiun regency to contribute to maintaining security. For his first time in history, 1,400 Champion of 14 Pencak Silat schools in Madiun district has been involved in the activities together which are held in Madiun Regency, Friday (26/10/2018), in the yard of Pendopo Ronggo Jumeno, Mejayan subdistrict, Madiun regency.

The vision and mission of the district government and the city government of Madiun must be accompanied by other stakeholders role efforts to make innovative breakthroughs as a form of conflict transformation, which is packing a gripping tradition into an interesting entertainment even as a tourist destination of culture that besides being believed to prevent conflicts especially in the month of Suro also expected to realize the achievement because the situation that is conducive to the event of the game between Pencak Silat, and is expected to provide a contribution to local revenue.

Based on the background outlined above, researchers are interested in focusing on research: "How to optimize stakeholder role in the handling of conflicts between Pencak Silat Setia Hati Terate (PSHT) and Pencak Silat Setia Winongo (PSHW) Regency and City of Madiun under Law No. 7 of 2012 and what are the obstacles? ". 


\section{Theory}

\subsection{Public Administration}

According to H. A Simon (in Handayaningrat, 1992), that "the administration is an activity of the group to conduct cooperation to complete a work based on the predetermined". Public administration in general can be interpreted as a process of cooperation conducted by all State apparatus to be able to perform its duties in accordance with the policy of predetermined state. According to Atmosudirdjo, in his book The Administrative law of the State provides the definition of State administration, that the State Administration has 3 (three) meanings: 1) as the state apparatus, apparatus of the Government or as a political institution (state). 2) as a function or as an activity to serve the Government, namely as an activity of operational administration. 3) As the technical process of law enforcement (Mustafa, 2001).

\subsection{Public Policy implementation}

Anderson (1984) defines policy as "The relationship of a Government Unit to its environment". Anderson (1984) concluded policy as "a purposive course of action, followed by an actor or a set of Actors in dealing with a problem or matter concern". According to Mazmanian and Sabatier (in Wahab, 2012) explains the meaning of implementation by saying that understanding what is in fact occurs after a program is declared valid or formulated that is a factor of the attention of policy implementation, Events and activities arising after the guidance of the Guidelines for public policy which includes both business attempts to administer it and to cause or effect on the community or the events Genesis.

Therefore, the Law Number 7 of year 2012 on social conflict handlers is implemented throughout Indonesia, including the districts and the city of Madiun, is to improve public services in the field of security and improvement The community economy, as stipulated in government Regulation Number 2 of year 2015 on the procedure of implementing social conflict management involving several stakeholder roles in it.

There are 3 (three) factors that can determine failure and success in the implementation of the policy namely: (a). Factors that lie in the formulation of policies that have been made by decision makers, (b). Factors located on implementing personnel, (c). The factor lies in the system of implementing organizations.

\subsection{Optimization}

Sons (2009) Optimizations can also be defined as a process for obtaining a state that provides the maximum or minimum value of a function. According to Sidik (2001) related to the optimization of an action or activity to enhance and optimize a role or implementation of activities. Characteristics of the optimization according to Yuniar (2017), namely: (a). The existence of the purpose in optimization can be a maximization or minimization form; (b). Alternative decisions, which are activities undertaken to obtain or achieve a goal; (c). The availability of resources is a sacrifice that must be made to achieve the stipulated objectives.

This optimization is indispensable for various activities related to favorable policies for communities and governments. The standard component of policy that can support or as a form of Linux is the clear legal basis, requirements, systems and mechanisms or procedures, the target time, budget, product development, facilities, infrastructure or facility, Implementation competencies, internal oversight, and commitment to provide a sense of security, free from harm, and performance evaluation.

\subsection{Role}

Soekanto (2002) defines the role as a dynamic aspect of the status, when a person carries out his obligations and rights according to his position, it can be said he has exercised a role. The role in this study corresponds to the basic tasks and functions of the status of stakeholders in the local government. The role of stakeholders is related to how to perform various tasks and functions optimally in handling the conflict between schools and Pencak Silat in the regency and city of Madiun. The role is carried out as a form of the assignment and authority of the regional head to perform a more well-coordinated synergist.

\subsection{Stakeholders}

Noguchi (2006) has a stakeholder as a person, group or institution that has a concern and can affect the outcome of an activity. Iqbal (2007) Describes stakeholders as those who have an impact or affected by the impact of a program, policy, and/or development. According to Nugroho (2014) stakeholders in the development program can be clarify based on their role, namely:

a. Policy creator, a stakeholder who serves as a decision maker and a policy determinant.

b. Coordinator, stakeholder who plays a role in coordinating other stakeholders involved.

c. Facilitator, a stakeholder who serves to facilitate and adequately what the target group needs.

d. Implementer, a policy implementing by stakeholder that includes a target group.

e. Accelerator, a stakeholder who has a role in accelerating and contributing so that a program can run on target or even faster when it is achievement.

\section{6. Conflict handling}

According to Soetopo (2012) The conflict is a contradiction and inconsistency of interests, objectives, and needs in the formal, social, and psychological situations, thus becoming antagonistic, ambivalent and emotional. Khayati (2013) suggests that the conflict handling is an action and reaction attack between perpetrators and outside parties in a conflict. 


\section{Research Methods}

The type of research used is a qualitative research approach that is descriptive (based on exploitation level), by using policy research (based on policy research method) that is focus on case study implementation A government policy. The focus of the point regard in this research is about optimizing stakeholder role in the handling of the inter-school conflict in the regency and Madiun city through the study of law implementation Number 7 of year 2012 about Handling social conflicts and also analyzing the obstacles, so as to know in detail how the efforts have been done so far.

The location of this research is in the Regency and Madiun city as the center of standing and the development of PSHT Pencak Silat and PSHW schools. The research site is the place to obtain the data and information used to answer the problems in accordance with the focus of the research to be researched. While the site in this research are the district government office and Madiun city,

a. Head office of regency and city of Madiun

b. Office of regional development planning regency and city of Madiun.

c. The office of the national unity and politics of the regency and Madiun city.

d. Police office of the regency and city of Madiun.

e. Military district command office 0803/madiun.

f. the office of youth, sports and tourism in the regency and city of Madiun.

g. The office of district trade, cooperatives, small and Madium micro businesse in the regency and city of Madiun.

h. The office of communication and informatics department of regency and city of Madiun.

i. The office of the region people's representative council in regency and Madiun city.

j. The office of the unity bond of Indonesian Pencak Silat regency secretariat and Madiun city (IPSI's office).

The method of data collection used in this study is interviews with stakeholders involved (regional head and head of related agencies) and observe. The analytical methods in this research are based on Creswell's analysis Method (2009):

a. Preparing data for analysis,

b. Read the entire data,

c. Conducting the coding process,

d. Describe the focus of research based on coding results,

e. Interpretation of data, conclusion collection.

\section{Results}

Researchers observed that the regency and the city of Madiun had a vision and mission of almost the same, which in general was to realize the Regency/city of Madiun that is safe, advanced, and prosperous. This means that one of the stakeholder roles is to create a sense of security for all communities in the Regency and city of Madiun. Researchers use the vision, mission and duties, functions and programmed of several stakeholders as well as the head of the related the organitation of regional to see the optimization of the role during this time with the stakeholder mapping theory.

\subsubsection{The role of policy creator}

The handling of social conflicts between the two Pencak Silat schools has been referring to the Law No. 7 of 2012. In the legislation mentioned that the local government led by the regional head as an element of government organizers commissioned an ad hoc conflict-of-affairs team consisting of the office of nation unity and politics of regency and Madiun City, Indonesian Army, Police and Leader of Pencak Silat College. The Regent commissioned the head of the National Unity and politics of the regency and Madiun city to coordinate with the Police office of the regency and city of Madiun and Military District Command Office 0803 Madiun and the manager of the Pencak Silat Regency of Madiun in preventing conflicts. Although in fact outside the conflict handler program there are also activities coordinated by the Tourism office, Youth and Sports in cooperation with the IPSI and Paguyuban Pencak Silat, but the agenda was entered into the cultural development Program through Budget planned by Office of Regional Development Planning Regency and City of Madiun.

The Regent of Madiun seeks to transform the conflict by organizing various events or activities in the development of Pencak Silat village such as "Festival Kampung Silat Indonesia" with Launching logo and "Parade 1000 Pencak Pendekar Silat". But the role of regent is less optimal because it has not made Local Regulations as a derivative Law number 7 of year 2012 about handling social conflicts to facilitate the optimization of stakeholder roles involved

Every effort undertaken by the Government of Madiun especially in the handling of social conflicts should be able to accommodate the interests of all parties to reduce or prevent people's suffering and enable the community to enjoy life in A State of Local Regulations peace and prosperity. It is in accordance with the expressed Frederick A. Cleveland cited by the Keban (2008) that: "The role of public administration is vital in helping empower society and create democracy. The public administration was held to provide public services and its benefits could be perceived by the public after the government increased its professionalism, applied efficiency and effectiveness techniques, and more profitable while the government can brighten the public to receive and operate some of the responsibilities of the public administration. "

As a form of enabling the community to enjoy life in a state of peace and prosperity, researchers saw that the mayor of Madiun had a role to demonstrate his desire towards the handling of conflict between Pencak Silat schools in Madiun and Change the tourism destination of art and culture Pencak Silat. The attention of mayor of Madiun through its mission vision of the mayor of Madiun was realized by holding the mayor Cup of 
Pencak Silat Nusantara Festival in commemoration of 100 years anniversary of Madiun City at the sport building Wilis Madiun on 27 July 2018.

The role of mayor as policy creator has been reconciling with a cultural approach. The Pencak Silat Nusantara Festival held by the government of Madiun is potentially a post-conflict integration medium. Efforts of the Government of Madiun make Pencak Silat icon as a tourism asset packed in the form of festivals are also potential in improving the welfare of the community. But the same as happened in Madiun, the innovation made is not optimal because it has not much involved related stakeholders (only used as leading sector the Office of Youth, Sports and Tourism regency and the city of Madiun and The office of nation unity and politics of regency and Madiun City that coordination meeting three pillars tends to be protocolar and involves not many stakeholders), and yet has a sustainable concept as a solution to conflict prevention The Equipment Organization Of Regional, realizing achievement and economically profitable.

The role of policy creator that should be run by the Regional People's Representative Council Regency and Madiun City regarding the handling of conflicts between the PSHT and PSHW school are still limited to carrying out supervision functions in the form of espousal in coordination meetings conducted by The Equipment Organization of Regional and the appeal to its constituents in the electoral regency (DAPIL) to be involved in maintaining security. In the coordination meeting, the new The Regional People's Representative Council played a role in the supervision function by giving agreement regarding the handling of conflicts such as the establishment of joint gate, joint development plan and the distribution of grants for the security forces in organizing security in the month of Suro/Muharam. As a policy creator, in order to optimize the role, the The Region Council Representative People must draft a regional regulation that regulates the handling of conflict to be discussed with the regent and formulated into regional regulations.

However, the Regional People's Representative Council Madiun Regency and The City of Madiun Legislators have not created a Perwali regarding the handling of conflicts between PSHT and PSHW universities because the government The Regional People's Representative Council Madiun has a Local Regulations number 8 of year 2010 about the change of the Local Regulations Madiun city number 04 of year 2006 about the implementation of peace and order. One of the substances of is a prohibition to perform acts that violate the norm of moral norms and disrupt order in public places and in public roads.

\subsubsection{The role of coordinator}

The Regional head with the role of policy creator can delegate authority and role as a coordinator to Office of Regional Development Planning Regency and City of Madiun District and city of Madiun. The Office of
Regional Development Planning Regency and City of Madiun as one of the that serves as a regional development planner should arrange and support the budget according to the approval of the regional head to coordinate technically The Equipment Organization Of Region as well as all stakeholders involved in the handling of conflicts between PSHT and PSHW. Although not optimal, but Office of Regional Development Planning Regency and City of Madiun has performed its role in planning activities including the following: first, perform coordination with the ranks of the Regional Leaders communication forum (FORKOPIMDA), so that in the last 2 (two) years of activity Suro/Muharam was held in the form of a parade that was assessed more regularly. Secondly, to strengthen the sense of the Brotherhood of Pencak Silat in Madiun Regency, also often displayed martial attractions from all the Pencak Silat College at major events. Thirdly, giving pride and flavor to have between Pencak Silat school in Madiun district by realizing Pencak Silat Village as one of the icons are still contested by the Regency and city of Madiun.

Some of the things that have not yet presented the optimal role of Office of Regional Development Planning Regency and City of Madiun include: first, the planning tasks are more submitted to the office of nation unity and politics of regency and Madiun City both the regency and the city of Madiun, including coordinating allocating and Grant distribution to security personnel. Office of Regional Development Planning Regency and City of Madiun only performs a general budget planning role for the development of Pencak Silat and has not divided in more detail activities related to the transformation of conflict handlers into the budget of some related The Equipment Organization of Regional; Second. The role of Office of Regional Development Planning Regency and City of Madiun as a coordinator during this period is less than optimal in coordinating the related service department so as not to own the road itself, even only submit the planning affairs of the conflict to The office of nation unity and politics of regency and Madiun City and security personnel; Thirdly, in planning activities (including budget allocation), Office of Regional Development Planning Regency and City of Madiun Madiun also still does not involve the wider role of The Equipment Organization Of Region to support the process of transforming the conflict into tourism destination of Pencak Silat art and culture.

The optimization of the Office of Regional Development Planning Regency and City of Madiun role must act as the single coordinator of all stakeholders regarding all planning tasks of conflict handling and transformation processes that have been delegated by the regional head. The Office of Regional Development Planning Regency and City of Madiun must return its instructions in coordinating the planned preparation by the Equipment Organization of Region in order to prevent any The Equipment Organization of Regional from running its own. Develop a budget plan that is devoted to the early detection activities against the potential of the 
conflict between Pencak Silat schools. Thus, it is hoped that the budget allocation will be on target to the relevant stakeholders, in the sense not only in the security post and achievement but also in the post that leads to packing a Pencak Silat as a destination Art tourism.

\subsubsection{The role of facility}

The role of the office of nation unity and politics of regency and Madiun City is most optimal than other The Equipment Organization of Regional in the handling of conflicts, maintaining a peaceful situation. Optimizing the role of the office of nation unity and politics of regency and Madiun City namely: (a). Facilitate the implementation of construction of IPSI members in the district or Madiun. (b). Facilitating the establishment of the Satgas Sentot Prawito Dirdjo which is a combination of young men from various Pencak Silat colleges. But Satgas Sentot Prawito Dirdjo whose membership includes the Regency and city of Madiun has not been built synergistically between the office of nation unity and politics of regency and Madiun City Regency and Madiun so that it runs on its own. (c) To facilitate the activities of each school Pencak Silat and security personnel through grant assistance. (d). To perform early detection together with the regional Intelligence Community (KOMINDA) to the situation in the field in the activities ahead of Suro. (e). Initiating the construction of a gate with the College of Pencak. (f). Create a decree of the Madiun regent on the Secretariat and Coordination team for social conflict and handlers. (g). Facilitate the mediation carried out as a form of reconciling PSHT and PSHW.

Department of Tourism and Sports District is not optimal in the optimization of conflict handling because in the event of traditional art of Pencak Silat held every week for all members of deserted Pencak Silat enthusiasts, The Office of Youth, Sports and Tourism district and the city of Madiun planned development Sports tourism that offers several aspects of recreational activities, personal development, or learn the uniqueness of the tourist attraction of Pencak Silat culture. The implementation of "Madiun Kampung Silat Indonesia" by holding "Parade 1.400 Champion" no prospect of its continuation.

While the tourism office, and the sport city of Madiun have made the following efforts: (a). Creating gymnastics and skills together involving IPSI and various Pencak Silat schools. (b). Disseminate the activities in the Festival of the fighter's village through the Ministry of Tourism and Tourism Office in East Java province. (c). Require that any activities of the level of the Government of Madiun, Pencak Silat is an attraction that must be displayed (d). Synergize with the Department of Communication and Information to conduct promotion (e). To plan the construction of the Padepokan together as Pusdiklat athlete as implemented by Madiun Regency.

The Education and culture Office of the Regency and the city of Madiun are not optimal in carrying out its role as a facilitator, this is because (a). In facilitating character building activities through the extracurricular Pencak Silat activities in schools, in the implementation does not involve related stakeholders such as IPSI and the group of Pencak Silat. (b). There is no monitoring to the Pencak Silat workshop in schools, so the need to conduct monitoring to the Pencak Silat workshop in schools before the implementation of the Agung Suran and must involve related stakeholders such as The office of nation unity and politics of regency and Madiun City, Security personnel including the internal security of Pencak Silat schools because through Synergist is expected to achieve other objectives other than the formation of early characters also handling conflicts with its transformation.

The facilitator role performed by the Department of Commerce, Cooperatives and Small and Madium Micro Businesse (UMKM) has not been seen optimally. The Department of Commerce, Cooperatives and Small and Madium Micro Businesse began their role during the Festival of Madiun Kampung Silat Indonesia in 2018. In the activities of the Department of Trade, Cooperatives and Small and Madium Micro Businesse prepare the stand Bazar used By Small and Madium Micro Businesse to sell their products such as souvenirs that are themed Pencak Silat. But for other activities such as Suro and Suran Agung, Small and Madium Micro Businesse still initiative themselves to jazz the activities. In the optimization of the Trade service, cooperatives and Small and Madium Micro Businesse should plan well the activities that are leading the sector, especially in the development of Small and Madium Micro Businesse to support the promotion of Madiun as the village Pencak Silat which is expected to be Improving people's living standards.

IPSI has a role in determining the realization of Pencak Silat achievement as a sport. But as we know that the performance of the Pencak Silat in Madiun both the city and the district are still very far from the expected. This is due to the lack of events that are smudged by IPSI with security considerations that have not been conducive. With this condition, the role that IPSI can do so far only facilitates the exercises along with training several representatives of the Pencak Silat School members to be delivered at the official events conducted by the local government.

\subsubsection{The implementer role}

The role carried out by the Madiun Kapolres in accordance with the Auth in maintaining security, order, and enforcing the law to the community has been implemented optimally. If there is anything less like the tension that occurred with the mass of fighters in the border Regional of Madiun regency on the implementation of Suro and Suran Agung, is still limited to the consequences of the law enforcement function expressly that must be an option Last instead of causing chaos due to clashing among the fighters ' masses. While the prevention function of conflict handling (socialization) has also been carried out optimally by the 
officials of the Kapolres over time through a dialogical approach involving all of stakeholders, especially Schools and Groups Pencak Silat until at grassroot level, because the degree of organization of Resort police can reach to the village level with the existence of The Public Security and Order Management that synergistic with the Indonesian Army element, namely Babinsa and head of village.

The role of Military District command 0803/ Madiun is to conduct socialization activities as a preventive and relief effort to support the Police and Madiun city has been implemented synergistically. Similarly, assistance to the local government and IPSI has been implemented optimally by conducting internal games Pencak Silat PSHT and PSHW.

The role of the school leadership and the Pencak Silat group have been optimal enough. Every conflict or planning activities in the month of Suro/Muharam, chairman and head of the Pencak Silat group always play an active role, coordinate with the security forces (Police and Army).

\subsubsection{Role accelerator}

The details of Madiun district has done its role as follows: (1) related to its task in the provocative news filter of the Pencak Silat Intercollegiate conflict, the role of Diskominfo is not optimal because there are still many Provocative news that circulates on social media that often cause tension between fighters (2) related to socialization about the activities of Madiun Kampung Pencak Silat Indonesia Diskominfo has enough to carry out its role with Spread the news about the festival that was conducted, but outside the activities Diskominfo less active in utilizing media capable of reaching up to grassroot level

The role of culture observer as an accelerator in the handling of conflicts is optimal, especially when seen from the involvement of culture observer actively in the seminary on National Insight that discusses Pencak Silat as an art and culture that teaches positive values. The district government and the city of Madiun must exploit the strategic position of the culture in delivering effective messages packaged in an entertaining light language. Such potential should be utilized optimally, other than to lower post-conflict tension also has a entertain value that appeals to the community.

\subsection{Obstacle problems}

Stakeholders in Madiun starting from the regent and mayor of Madiun, the related The Equipment Organization of Regional, the security personnel, the head of the school and Pencak Silat group to the culture and journalists have made efforts and activities to prevent, stop, terminate and to restore conflicts with reconciliation, rehabilitation, and reconstruction despite not having demonstrated optimal results.

With regards to the handling of conflicts, succeeded in the implementation of the optimal role of stakeholders can be seen from Edward III (Edward III, 1984), quoted by Abdullah (2015) that the success of role optimization is influenced by factors that are the most important requirement of success of the process optimization of roles and implementation are: communication, resources, disposition, attitude, commitment, and bureaucratic structure. Related to communication, resources, disposition, attitude, and commitment, so far it can be fulfilled by most stakeholder and a small part that has not been able to meet these requirements, especially The Equipment Organization of Regional that still assumes that the handling of conflicts is not a ration. It is still the main problem as the successful condition of optimization is related to the bureaucratic structure in which there is no standard rules and strict as a common guideline for all stakeholders in carrying out their So that the void of role and overlap (not coordinated through good synergist). The constraints of constraints that become barriers to the optimization of stakeholder role in the handling of conflicts between PSHT and PSHW in the Regency and Madiun City are.

The main obstacle is the absence of policy formulation made by decision makers and is applicative, clear, understandable, easy to interpret, on target and involve all of stakeholder that related such as local regulation, regent Regulation or mayor or SOP mutual as a derivative of Law No. 7 of year 2012 on social conflict handling. With this condition, the post-conflict handling especially in events in the month of Suro/ Muharam tends to be done only by the security forces, while the local government and the city of Madiun only make the problem as the Auth the office of nation unity and politics of regency and Madiun City only.

Constraints related to the system of implementing organization, researchers see that both the Regent and mayor in running the program tend to run according to its territory responsibilities, when the target program (fighters) and places of activity is not limited by the region. Therefore, synergist between the district government and the city of Madiun must be done by setting aside the individual sectoral ego. The Government of the regency and Madiun have their own program and jargon to make the same icon of Pencak Silat in its region. That becomes a dilemma when each region has its own authority in determining its policies, moreover it relates to potential territories and budgets that are unlikely to be united.

\section{Discussion and conclusion}

Based on the mapping of stakeholder's roles related to the optimization of stakeholder role in the implementation of law number 7 of year 2012 concerning the handling of social conflicts between PSHT and PSHW in the regency and city of Madiun. Role of policy Creator who has high power and importance in formulating policies such as: Regent and Mayor of regency, The Regional People's Representative Council of Regency and Madiun City.

The role of the coordinator who is the key coordination between head of Regency and all the The Equipment Organization of Regional involved, namely Office of Regional Development Planning Regency and City of Madiun Regency and Madiun City. The role of the 
facilitator who has the authority to provide construction facilities and development of Pencak Silat culture is: The Office of the National Unity and politics of the regency and Madiun city; Tourism office, Youth and Sports; Education and culture Office; Department of Trade Cooperatives and Small and Medium Micro Businesse of Regency and Kota Madiun; IPSI Regency and City of Madiun.

The role of Implementer that has the authority to maintain security and peace as a form of conflict handling between PSHT and PSHW namely: Resort Police Regency and City of Madiun, Military District Command Office 0803/ Madiun, group of Pencak Silat Regency and Madiun city. The role of Accelerator that has the authority to accelerate the occurrence of good influence in the transformation of conflict by changing the conflict into tourist destinations of Pencak Silat Culture is the Department of Communication and Informatics Regency and Madiun City, and Humanist.

Optimizing stakeholder role in handling social conflict between PSHT and PSHW in Regency and Madiun City is less optimal if seen from the mapping of stakeholder role. As for the constraints resulting in less optimal stakeholder roles. The absence of Law No. 7 of 2012 on social conflict management in the Regency and city of Madiun that clearly and firmly regulates the involvement of relevant stakeholders and how synergically because this is only done through a security approach by the security forces in the form of a Temporary security team (ad hoc).There is no synergist due to the sectoral ego between the District government and the city of Madiun, so that each government impressed "scramble" the icon of Pencak Silat.

\section{References}

Anderson, E. (1984). Public Policy Making. Holt, Rinehartand Winston.

Handayaningrat, S. (1996). Introduction to Administration and management sciences. CV. Massasung.

Keban, Y. (2004). Six strategic dimensions of public administration, concepts, theories, and issues. Gava Media.

Riant, N. (2014). Public Policy. Elex Media Computindo.

Sidik, M. (2001). In the Seminar creating Good Governance in support of regional autonomy and fiscal decentralization. Yogyakarta. 20 April 2001

Soekanto, S. (1989). Sociology of an introduction. Press Rajawali. Jakarta

Sri, W. (2015). Optimization of early detection ability and mitigation of conflict risk by the unit of Koramil in the prevention of social conflicts and the implications of regional resilience (study in Koramil 05/Pasar Kliwon, KODIM 0735/Surakarta, Central Java). Journal of National Resilience, 21(3)1-8.

Suwitri, S. (2009). Basic concepts of public policy. Semarang: The publishing agency of Diponegoro University.
Wahab, S. (1991). Policy analysis from formulations to the immigration policy of the country. Bumi Aksara. 